\title{
NÄRPOLISEN OCH BROTTSBEKÄMPNINGEN ${ }^{1}$
}

\section{Av RIKSPOLISCHEF STEN HeCKSCHER}

Community policing is built on knowledge, analysis and planning, which requires an evaluation of police procedures and accomplishments. It therefore becomes necessary for the police to work more closely with others, which results in the police being more open. This, together with other changes, has improved the relations between the police and the research community. Researchers are nowadays more interested in research on police work, and the police are more interested in taking advantage of the results.

Collaboration between the police and the research community has been fueled by the advent of community policing, which embraces both more open attitudes and an increased respect for academic knowledge and techniques. Changes in the educational requirements for police recruits, as well as in the amount of training these recruits receive, has led to the hiring of a more "academic-friendly" police force. All of this has strengthened the relationship between police officers and the research community.*

Jag tycker att närpolisreformen är bra. Jag tror på den som en förnyande och förbättrande kraft i polisarbetet.

Det betyder inte att jag anser att allt i förändringen är som på bröllop. Tvärtom finns självfallet svårigheter, risker och tillkortakommanden.

Men för var och en som är optimistisk nog att tro att kunskap och tänkande är viktiga inslag i ett utvecklingsarbete, och att en verksamhet som bygger på kunskap lyckas bättre än en som inte gör det, kan närpolisreformen knappast vara något annat än ett steg i rätt riktning.

Jag skall försöka bidra till dagens diskussion inte så mycket genom att ge en skildring av förhållandena i Sverige, utan snarare med några lite mer principiella synpunkter.

Jag tänker tala om

- Vad är egentligen närpolisreformen?

- Vad är bra med reformen?

- Polisen och forskningen

- Vilka är farorna och riskerna med reformen?

- Vad har gått mindre bra i förändringen?

1 Denna text återger någorlunda väl ett anförande vid Det Nordiska Kriminalistmötet i Oslo 000606.

* Title in English: Community Policing and Crime Prevention. Original in Swedish. 


\section{Vad är närpolisreformen?}

Närpolisen är främst en organisatorisk konsekvens av nya principer för hur polisarbete skall bedrivas.

I Sverige kallas det för problemorienterat polisarbete. Det är en term som jag i och för sig inte gillar så mycket; dels för att den är abstrakt, dels för att den är onödigt deprimerande. Men jag skall inte fördjupa mig i en begreppsdiskussion utan i stället säga att

- det är en arbetsmetod som bygger på kunskap, och inte bara på den kunskap man själv har

- det är en arbetsmetod som fordrar att man systematiserar sina erfarenheter och inte bara slappt säger att man redan vet hur allting är

- det är en arbetsmetod som kräver att polisen samlar data, analyserar dem och planerar sin verksamhet med analysen som utgångspunkt

- det är en arbetsmetod som lägger mera vikt vid det brottsförebyggande

- det är en arbetsmetod som är öppen för genomlysning och insyn och som förutsätter utvärdering

Däremot är en närpolis inte något särskilt polisdjur, artfrämmande för andra poliser. I vart fall skall det inte vara så. Att man ibland kan få det intrycket kan möjligen bero just på att man inte inser att det främst rör sig om en organisatorisk konsekvens av något annat, nämligen ett sätt att bedriva polisarbete.

I Sverige har den s.k. närpolisreformen satt sin prägel på större delen av 90talet. Det man tycker är bra med polisens utveckling hänförs till den förändringen lika väl som allt man tycker är dåligt.

Med mitt sätt att se blir detta en aning perspektivlöst. Det finns nämligen också andra förändringar under samma tid som har haft stor betydelse för polisens arbete, åtminstone i Sverige.

Dit hör

- strukturreformen, från 117 polismyndigheter till 21

- en ekonomisk knapphet, egentligen för första gången sedan förstatligandet år 1965

- ett ökat politiskt intresse för kriminalitet i allmänhet och polisarbete i synnerhet

\section{Men vad är bra med närpolisreformen?}

Jag tror att närpolisreformen i Sverige har blivit en spjutspets för ett polisarbete som

- bygger på kunskap

- bygger på analys och planering

• gör utvärdering nödvändig

- gör det naturligt för polisen att i högre grad än förr arbeta tillsammans med andra

- över huvud taget öppnar polisen och för polisen närmare medborgarna 
Och jag menar dessutom att ett sådant polisarbete - allt annat lika - leder till ett bättre resultat, dvs. fler lagförda och färre brott.

Men är det här egentligen nytt? En vanlig attityd bland poliser är t ex att så här har vi alltid jobbat.

Tja, vad är nytt? Att man försöker bygga sitt jobb på kunskaper och analyser är förhoppningsvis inte alldeles nytt. Och t.ex. kvalificerat kriminalpolisarbete har väl alltid haft sådan prägel, låt vara att där inte funnits några särskilt uttalade brottsförebyggande ambitioner.

Men visst innebär den här förändringen något nytt! Framför allt kravet att gå från att vara bara reaktiv, att hoppa när någon drar i snöret, till att också vara proaktiv.

Och dessutom, jag menar att det är nytt med kravet på att den här attityden skall genomsyra allt polisarbete. Och vad som också är nytt, åtminstone för svenskt vidkommande, är statsmaktens intresse av att mera systematiskt försöka ta reda på vad alla poliskronor leder till för resultat. Och där finns en länk till det nya i polisarbetet, nämligen ambitionen att

- analysera

- planera

- genomföra

- följa upp

\section{Polisen och forskningen}

Kanske kunde det vara på sin plats att just här och nu säga ytterligare några ord om vilken betydelse den här reformen kan ha haft och kan komma att få för polisens relationer och samverkan med forskarsamhället och för polisens förmåga att dra nytta av den forskning som utförs.

Om man ser den saken i några decenniers perspektiv, så påstår jag att förhållandet mellan polis och forskare, åtminstone i Sverige, har varit rätt frostigt. Jag tror att det har varit en ömsesidig misstro - som så ofta grundad på bl.a. ömsesidig brist på kunskap och inlevelse - och misstron har säkert, åtminstone delvis, varit berättigad.

Polisen har inte hyst något större intresse för forskares arbete eller respekt för deras resultat. I den mån de hört talas om sådana resultat eller till och med tagit del av dem, så har det legat nära till hands att avfärda dem. Jag tror att det här har gällt rakt igenom de polisiära hierarkierna, låt vara att det funnits fickor av en mera positiv hållning lite här och där.

Ser man till forskarsamhället, så har den grundläggande attityden knappast varit så värst mycket mera positiv. Kanske inte tidigare funnits något har det särskilt stort intresse för polisforskning, låt vara att det fanns några stycken som under senare delen av 70-talet gjorde vissa försök att etablera polisforskning i nordiska länder. Men forskarsamhället har haft sitt fokus åt helt andra håll.

Det här är numera inte alls som förr. Vad det beror på vet jag inte, men jag kan tillåta mig att spekulera. 
En förklaring kan finnas att söka i samhällsklimatet. För säg 30 år sedan fanns det i radikala kretsar, och dit hörde väl kriminologerna i regel då, en nästan intuitiv motvilja och skepsis mot polisen. (Nu kunde man ju tycka att skepsis skulle vara en bra utgångspunkt för kritisk forskning, men det tycks inte ha hjälpt upp intresset för att forska om polisen.) Samma skepsis fanns för övrigt också på andra håll. Det ligger nära till hands att erinra om det närmast väpnade tillstånd som rådde mellan polisen och socialarbetarna, ett tillstånd som förändrats så till den grad att man ibland undrar hur starka de ömsesidiga identiteterna numera egentligen är; mer om detta strax.

Men det är inte alldeles omöjligt att inbilla sig att det numera ganska starka intresset för att beforska polisen kan ha något att göra med nya principer och former för polisarbete. Och att också det påverkat attityderna, åtminstone inom polisen kraftigt.

Det här är nu inte så konstigt; jag menar, om det ställs krav på att polisen i högre grad än tidigare skall bygga sina arbetsmetoder på kunskap, på analys och planering, så vore det inte så konstigt om detta, åtminstone på sikt, påverkade polisens attityd till forskning. Och om polisen dessutom måste kontinuerligt försöka ta rätt på vad de egna ansträngningarna leder till för resultat, får man behov av och därmed ett ökat intresse för och en större öppenhet gentemot forskarvärlden.

Forskarna var dessutom redan från början delaktiga i den här reformen. I själva verket var den forskar- och kunskapsdriven, vilket kanske kan glädja den som frustrerat brukar reflektera över etablissemangets ovilja och oförmåga att ta till sig kunskap och beprövad erfarenhet.

I själva verket finns nu en viktig nisch för forskning om polisen och inom polisen. Och polisens attityd till att låta sig beforskas är en helt annan nu än den var för 25 eller 30 år sedan. Det är bra, och det leder för övrigt också till bl.a. att poliser forskar, både i den etablerade mera begränsade meningen, men också som ett led i det dagliga arbetet.

Jag tror att det här också har fătt andra mycket goda effekter. Jag tycker mig åtminstone se att polisers attityder till ny kunskap och till kunskaper och erfarenheter som andra än poliser har avsevärt förändras. Det finns i och för sig också andra skäl till det; t.ex. en gradvis förändrad rekrytering och hos oss nya principer för meritering och karriär. Polisutbildningen har successivt förändrats, och dess akademiska ambitioner blivit märkbara. Forskning har etablerats vid eller med anknytning till polishögskolorna.

I själva verket blir det här självförstärkande, en god spiral.

Kunskaperna blir större både inom polisen och om polisen. Attityderna till ny kunskap blir därmed öppnare, och då blir även organisationen som sådan öppnare, något som är angeläget $i$ en kårorganisation med sådana organisationers traditioner av viss slutenhet. Och allt detta hjälper dessutom på sikt till med att komma åt de mindre lyckade inslagen i en stark poliskultur. 
Sammantaget finns det numera en betydelsefull och mera lätt tillgänglig nisch för kriminologer och andra forskare i polisens utvecklingsarbete. Jag är övertygad om att det är bra för oss alla.

\section{Riskerna med reformen?}

Men nu frågar ni er naturligtvis, och det med rätta, skall den här lovsången aldrig ta slut? Finns det över huvud taget inga bekymmer med det här? Finns det inga risker, inga faror, inga misslyckanden eller tillkortakommanden?

Jo, naturligtvis finns det. Mig veterligt finns inga förändringar, möjligen undantagandes sommartiden, som inte har både bra och dåliga sidor.

Jag har nyss snuddat vid en av de risker som jag tycker varit mest tydlig. Det är att identiteten riskerar att suddas ut, inte bara för poliser utan också för andra yrkeskategorier som lärare och socialarbetare.

Närpolisens arbete och arbetssätt ställer krav på samverkan med andra och ökad förståelse för andras arbetsuppgifter och synsätt. Polisen skall också arbeta på delvis nya arenor. Samtidigt får man medge att statsmaktens anvisningar för förändringen inte alltid varit glasklara och att polisens förmåga att genomföra den inte alltid varit lika målmedveten och stringent eller för den delen kunskapsorienterad, öppen eller kunskapsvänlig. Det är dessutom naturligt, ja önskvärt, att ge rätt stora frihetsgrader vid en förändring av det här slaget när det gäller att finna nya former. Allt sammantaget har bilden av vad polisen skall göra blivit otydligare. Och därmed polisens identitet.

Jag tycker det här är intressant. Jag spekulerar om tre samtida företeelser som tillsammans ökar risken för en identitetskris hos närpolisen, och faktiskt också hos andra.

- Kraven på att arbeta på ett nytt sätt och tillsammans med andra, kanske främst kommunala organ som skola, socialtjänst, fritidsförvaltning etc. Nya arenor, nya arbetsformer, nya arbetsuppgifter, utanför det som hört till det traditionella polisarbetet.

- Ekonomisk knapphet under 90-talet även i den kommunala sektorn och en mera positiv attityd till polisen - man har gärna, och på ett helt annat sätt än 20 år tidigare, sett att poliser tagit på sig uppgifter inom skola, fritidsförvaltning etc.

- Ett drag i den polisiära kulturen att tro sig mycket bra veta hur även andra borde sköta sitt jobb, inte minst t.ex. socialtjänsten. Och därmed en beredskap, ibland till och med en önskan att ta på sig också sådana uppgifter.

När dessa faktorer samverkar, och det har de gjort, riskerar polisens identitet att gröpas ur. Det finns en påtaglig och manifesterad risk att polisen sätter i gång att syssla med allt möjligt som dels polisen inte har kompetens för, dels knappast kan betraktas som polisiärt relevant. 
Här gäller det att vara vaksam. Och dessutom inse att vad som vid en viss tid på en viss plats och under vissa förutsättningar kan vara polisiärt relevant, inte därmed med nödvändighet är det vid en annan tid, eller på en annan plats eller under andra förhållanden.

Här blir åter nyckelorden

- analys

- målformulering

- planering

- genomförande

- uppföljning

Och om allt detta hänger ihop, kan även oväntade aktiviteter vara försvarbara.

Men det är inte bara polisens identitet som kan gröpas ut. Detsamma gäller naturligtvis de yrkesgrupper vilkas arbetsuppgifter polisen tar över, t.ex. skolan eller socialtjänsten.

Och det leder osökt över till en annan risk som har att göra med etablerade anspråk på integritet.

Om t.ex. polisens relationer med socialtjänsten eller sjukvården blir alltför intima, då är det lätt hänt att information sprids till polisen på ett sätt som inte är tänkt och som på sikt kan gröpa ur och äventyra också dessa funktioners identitet, integritet och förtroende. Och i ett bredare perspektiv är det klart att duktiga polisers framgångsrika kartläggning av förhållandena i närsamhället leder till mycket goda kunskaper om närsamhällets befolkning; deras vanor och ovanor, deras relationer osv. Det är svårt att komma ifrån. Men polisen har onekligen sedan länge stor vana vid att hantera sådana delikata kunskaper. Och jag känner mig övertygad att denna balansgång också i regel sköts på ett bra sätt.

I ett polisiärt perspektiv vill jag slutligen peka på ännu en risk.

Jag tror mycket övertygat på behovet av en stark nationell polis. I många andra länder är bilden en annan, och det är ingen uppmuntrande bild. Konkurrerande polisorganisationer med behov av att hävda sig och med oklar arbetsfördelning. Konkurrerande kompetenser på samma geografiska områden. Det skapar oreda och lägre effektivitet. Flexibiliteten försvinner, och möjligheterna till nationell samordning i särskilt svåra situationer sätts på spel.

Med höga frihetsgrader och en naturlig anpassning till lokala förhållanden finns det en risk för att i och för sig önskvärda variationer i polisarbetets organisation och metoder leder somliga till den förhastade slutsatsen att också ansvaret för polisen lika gärna kunde vara lokalt, kommunalt.

Det vore olyckligt.

I Sverige har vi erfarenheter av en kommunal polis från tiden före år 1965. I rika kommuner hade polisen ofta mera resurser än i fattiga trots att behoven ofta var omvända. Poliser måste också kunna röra sig över administrativa gränser, och med en kommunal polis skapar det oreda. Krav på utrustning blir alltför 
varierande, och möjligheterna till samverkan dåliga. Det finns också andra allvarliga olägenheter med en kommunaliserad polis.

\section{Vad har gått mindre bra vid förändringen?}

Det man oftast hör talas om är att tidpunkten för förändringen var illa vald. Den genomfördes under en period då inga nya resurser tillfördes polisen utan organisationen tvärtom tvingades krympa.

Det ligger en del i den kritiken. Det kan inte bestridas att nya arbetsuppgifter följde av förändringen och att dessutom många poliser samtidigt var tvungna att lära nytt. Och att etablerade strukturer bröts ner och att särskilt brottsutredningsverksamheten tog en hel del stryk. Olägenheterna förstärktes av att också andra strukturförändringar ägde rum vid samma tid Och en ovan brist på resurser i en organisation, och trasiga informella strukturer, skapar lätt otrygghet och en gnällig stämning som inte främjar förändringar.

Samtidigt måste man medge att reformen var angelägen, och att den inte rimligen kunde anstå tills man på nytt kunde rulla sig som Joakim von Anka. Man bör inte glömma att grundtanken faktiskt är att få mer och bättre polisarbete utfört med bättre resultat för uppgiften. Och det är inte mindre angeläget när resurserna är knappa, kanske snarare tvärtom.

Det har varit svårt och tagit lång tid att få förändringen att slå igenom inom polisen. Det är en stor organisation och en åsiktsstark organisation, och garantierna för kontinuitet är starka.

På sina håll har det funnits tendenser till att man byggt vallgravar mellan vad man sagt vara olika "sorters" poliser och polisarbete. Velourpoliser som leker på dagis och hjälper äldre över gatan vs starka ordningspoliser i utryckning som får träda in när det verkligen behövs en polis. let.

Här har säkert formerna för att lansera förändringen haft sitt finger med i spe-

I de nordiska länderna är vi duktiga och noggranna när vi överväger och planerar förändringar. Vi utreder, remissbehandlar och funderar. Vi väger fördelar mot nackdelar, och så småningom fattar vi ett beslut.

Men för det första är vi ofta alltför beslutsfixerade. Vi tror att det är själva beslutet som är det viktiga, ett slags slutpunkt, när vi i stället borde ägna oss mera åt resultatet av beslutet, förändringen.

För det andra går vi ofta i fällan att direkt efter beslutet glömma bort vad det var som talade mot den lösning vi valde. Vi bär oss åt som missionärer och predikar, ibland onyanserat, beslutets och förändringens lov. Det finns en ibland förverkligad risk för att vi sparkar in de obestridliga nackdelarna under mattan och låtsas att de inte existerar.

Då händer lätt två saker. Dels förlorar vi trovärdighet; inte ens de som tyckte beslutet var bra känner igen sig i vår beskrivning. Dels, och värre, försummar vi lätt att ta hand om de ofrånkomliga och mindre lyckade konsekvenserna av vårt i och för sig väl avvägda och kloka beslut. 
Det här är inget specifikt för polisen. Jag har sett det i näringslivet, i förvaltningen och i politiken. Det blir för mycket av svart och vitt, för lite av nyanser.

Om vi i Sverige skulle göra om närpolisreformen, så tror jag alltså att en mer ödmjuk hållning vore välgörande. Och mindre av dekret uppifrån, mer av lyhörd samverkan med dem som skall genomföra reformen.

Jag tror också att det är viktigt att betrakta närpoliser just som vanliga poliser och inte som en särskild ras. En del av de motsättningar och fördomar som finns - och framför allt funnits - inom organisationen kan då bemästras bättre.

Och gränsen mellan närpoliser och poliser i traditionell ingripandeverksamhet blir efter hand lösare. Jag tror att det inte är någon nackdel så länge man slår vakt om den problemorienterade inriktningen. Närpoliser har i regel ett totalansvar för polisverksamheten inom ett visst geografiskt område. Jag tror själv det är viktigt att poliser inom närpolisen sysslar med all slags polisverksamhet:

- allmän övervakning

- trafikövervakning

- ingripanden av olika slag

- brottsutredningar

- brottsförebyggande arbete

- etc.

I själva verket är mångfalden i arbetsuppgifterna också ett sätt att skaffa sig den goda kännedom om förhållandena i det egna området som behövs för ett bra polisarbete.

$\mathrm{Nu}$ är jag emellertid optimistisk nog att tro att olägenheterna med reformen kan betraktas som barnsjukdomar, låt vara att de ibland kan förekomma rätt långt upp i åldrarna. Och att närpolisen och det problemorienterade polisarbetet med mera fokus på att försöka förebygga brott har kommit för att stanna. Men det finns ett pedagogiskt ansvar som då inte får försummas.

För att sammanfatta.

- Närpolisen är främst en organisatorisk konsekvens av en principiell och positiv förändring av polisarbete, av en stark orientering mot att bygga arbetet på kunskap.

- En mer analytisk grund för polisens arbete ger en god grund för att forskarsamhället och polisen kommer närmare varandra, något som båda har haft och kommer att få stor nytta av.

- Närpoliser är inte en särskild polisras.

- Det är viktigt att analysera och balansera de obestridliga riskerna med förändringen, kanske främst att värna den polisiära identiteten.

Adress: Rikspolisstyrelsen

Box 12256

SE - 10226 Stockholm 